\title{
sciendo FAULT TREE ANALYSIS AS A TOOL TO INCREASE THE LEVEL OF SECURITY IN AN ENTERPRISE
}

doi:10.2478/mape-2018-0091

Date of submission of the article to the Editor: 04/2018

Date of acceptance of the article by the Editor: 07/2018

MAPE 2018, volume 1, issue 1, pp. 719-725

Dr inż. Jolanta Ignac-Nowicka

Silesian University of Technology, Poland

RNDr. Tibor Krenický, PhD.

Technical University Kosice, Slovak Republic

\begin{abstract}
Technological progress, as well as the development of the sciences on occupational health and safety, increased safety and improved working conditions in enterprises of even the most onerous industries. To maintain the required level of safety, preventive actions are taken to identify all hazards in the workplace. In practice, many methods are used to identify hazards depending on the type of technological processes and the types of workstations analyzed. The article presents the advantages of the fault tree analysis method as a tool to support the process safety management in the enterprise. The article presents features of the fault tree analysis method as a tool for better security management in an enterprise. Cause and effect relationships between events in the fault tree schema on selected examples were examined. Indirect and direct causes of accidents and failures in the enterprise have been identified, including human errors (human factor). The use of the fault tree analysis method to support accident and failure risk assessment in an industrial plant was also analyzed.
\end{abstract}

Keywords: fault tree analysis, human factor, hazards in the workplace, risk assessment

\section{INTRODUCTION}

The development of new technologies led to advances in the field of security systems. However, technological development has not eliminated industrial accidents and failures in the work environment. Developing effective tools to ensure workplace safety is still necessary. Enterprise security management is based on the continuous identification and control of threats. The hazard can be defined as a specific factor that in certain circumstances can cause damage to the system element: man - af technical object - environment. One or more dangers may be present for each dangerous situation. Hazards are often a combination of dangerous situations and dangerous ways to implement certain activities in the human-machine system (Kalinowski, 2003).

Hazards can be classified, which can be a valuable tool for identifying and prioritizing their removal. Four hazard classes can be distinguished: marginal, critical and catastrophic. In the case of marginal hazards, the damage will not cause serious damage to the system or injury to the service personnel. Critical hazards are system damages that cause personal injury and / or material damage. This is an effect of an unacceptable threat requiring immediate corrective action. In turn, a catastrophic hazard causes serious impairment of the system, death and injury to personnel (Studenski, 1996).

Due to the source of danger, three basic groups of threats can be distinguished: technical, human factors (human errors) and environmental hazards. Apart from typical technical hazards coming from machines, devices and tools, hazards from the human factor often appear. They result from the workload of the employee with physical factors (including the material working environment) and mental factors as a result of high demands placed on the employee in the work process. Technical hazards and human errors constitute a specific 
combination of sources of danger, often leading to failure or accident. The third group of risks is described as a threat to the environment, for example due to the toxicity of the industrial process (contamination of air, water and soil) or sudden uncontrolled release of toxic substances or radiation to the environment. In particular, industrial disasters are contamination of the work environment and natural environment.

The occurrence of hazards may generate losses and this forces the entrepreneurs to assess the existing risk, which is a combination of the frequency of occurrence of the hazard and the size of losses associated with this hazard. The analysis leading to the disclosure of all events affecting the presence of a given threat is an important element of the risk analysis procedure at the workplace. However, the possibility of taking corrective actions as a result of the analysis of the fault tree (FTA) leads to an effective reduction of occupational risk, which is an obligation of every employer.

\section{HAZARD IDENTIFICATION AS THE MOST IMPORTANT ELEMENT IN THE ASSESSMENT OF THE SIZE OF RISK}

Ensuring safety at the workplace requires a detailed hazard identification, quantitative and qualitative risk assessment. Then, if the level of risk is assessed as too high and unacceptable, a decision is made to reduce this risk. At the workplace, accepted risk is managed. Risk management is an organizational process aimed at maintaining risk in a controlled state. Risk analysis is a procedure and assumes that the risk is composed of two elements: the probability of injury, loss of health and/or other losses and the severity of possible injury to the body, deterioration of health and/or other losses (Bobrowski, 1980). The procedure focused on reducing and controlling the risk is shown in the diagram in Figure 1.

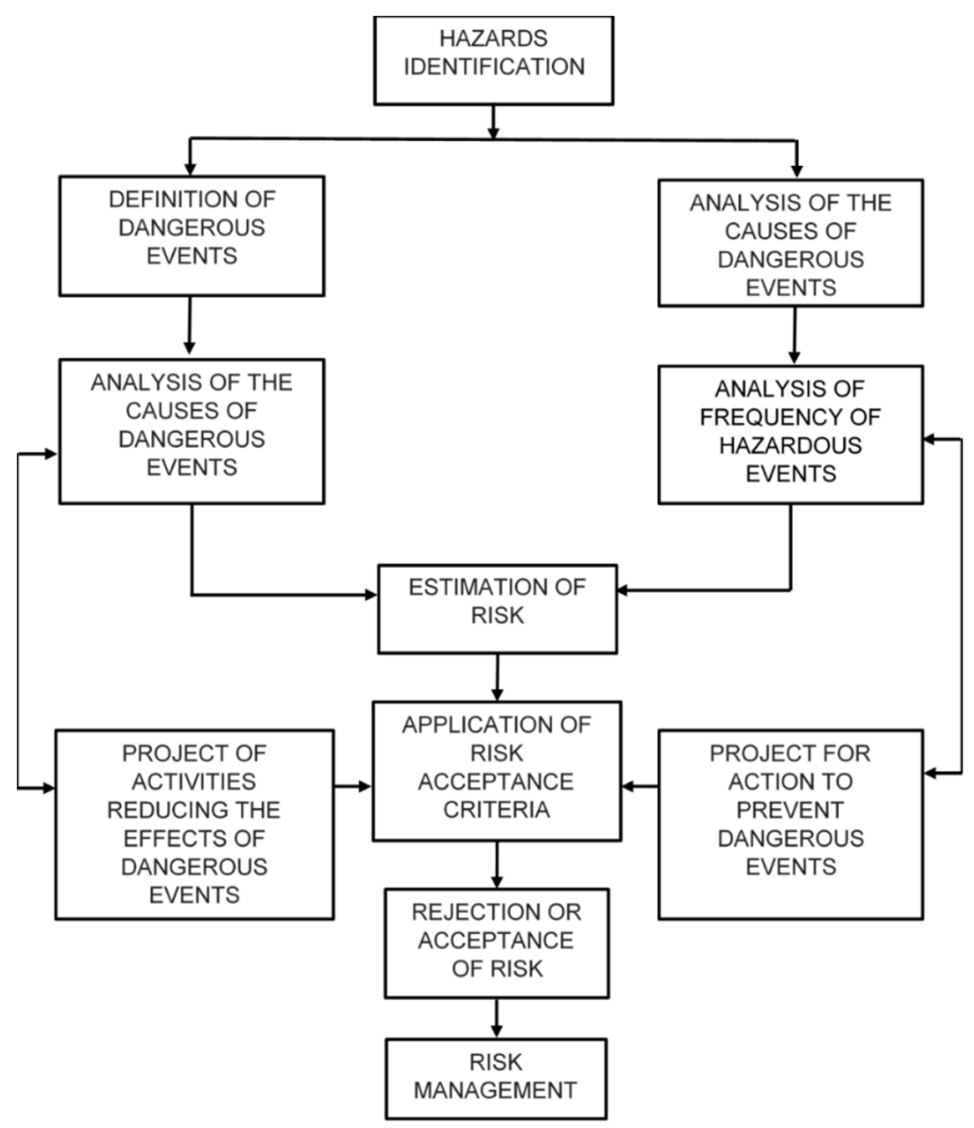

Fig. 1. Diagram of the risk analysis procedure in an enterprise

Source: (Studenski, 1996). 
Risk analysis includes several stages, such as:

- defining the boundaries of the object for which the risk assessment is performed,

- preparation of a list of identified hazards,

- risk assessment, that is, determination of possible consequences and their probability,

- reading the risk value from the matrix (PN-N-18001, 2004).

The most important step is to identify all hazards. Before identifying threats, it is recommended to specify how to collect information about hazards occurring at the workplace. Identifying hazards can be supported by the use of special tools to improve the recognition of the causes of dangerous events.

\section{HAZARD IDENTIFICATION - RESEARCH METHODOLOGY}

There are many methods for identifying hazards in the subject matter literature. Most often, these are retrospective methods such as document analysis, checklists, or accident card analysis. For identifying dynamic dangers (for example gas hazards), prospective methods of hazard identification are most commonly used (Pauliček et al., 2012). They involve identifying threats and anticipating possible threats. These include: change analysis, failure mode and effect analysis (FMEA) (Kotus et al., 2014, Hąbek and Molenda, 2017), gross hazard analysis (GHA), hazard and operability analysis (HAZOP), job safety analysis (JSA), technique of operations review (TOR), total job analysis (TJA). In the processes of machines and people work, deductive methods are often used, such as: fault tree analysis (FTA), event tree analysis (ETA) and analysis of the event chain using elements of the theory of events (Ignac-Nowicka, 2017, 2015).

During the project, when there is little or no detailed information, the PHA (Preliminary Hazard Analysis) method is often used as a precursor for further research. The PHA risk estimation should be adjusted and updated, as necessary in the next steps of the risk analysis procedure, in each stage of the design, construction and exploitation tests. PHA analysis is an inductive method that allows a qualitative risk assessment (Idzikowski, 2011).

In the analysis of technical hazards arising from the operation of the gas installation and auxiliary equipment, it is preferable to use such identification methods as: fault tree method, event tree method, high hazard analysis, failure analysis and their effects, and process hazards analysis.

The fault tree method (FTA), due to its specificity, has a limited scope of application, but leads in a simple way to determine the causes of threats and shows their logical interrelations. This method sets events whose combinations lead to a peak event. In this way create, the so-called fault tree, where the events are connected by logic gates "or", "and". The FTA method can be used to describe events involving technical means (machines) and man (working crew). In this method, it is possible to take into account both emergency events of technical elements and failures resulting from human error (human factor). It gives the possibility of a wider analysis of the causes and effects that lead to the final event in the form of accident or technical failure (Ignac-Nowicka, 2017, 2018).

\section{APPLICATION OF FAULT TREE ANALYSIS FOR HAZARDS IDENTIFICATION AND THEIR CAUSES}

The event tree analysis (FTA) is a tool to graphically indicate possible sequences of events that ultimately led to or could lead to machine failure or an accident. Such analysis makes it possible to exclude certain events by preventing them from occurring. In this way, the level of risk taken in a given situation is reduced by reducing or eliminating the hazard. Figure 2 shows the scheme of the error tree for the event: machine destruction. 


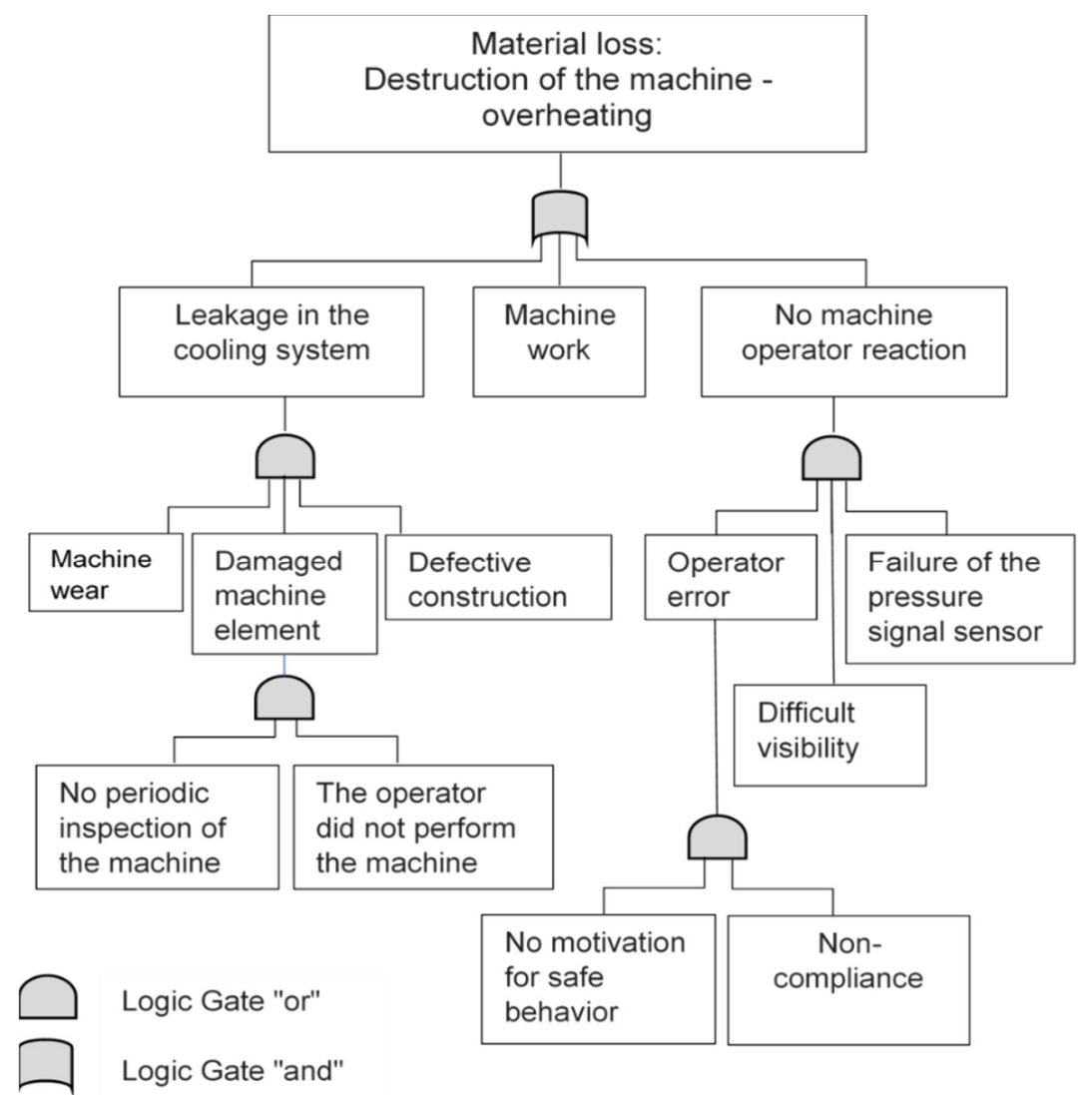

Fig. 2. Diagram of fault tree for the event: destruction of the machine

In the analyzed case, the threat in the form of material loss occurs when there are certain intermediate events. In this example, the machine failed due to overheating, which could occur with the simultaneous occurrence of three events: leaks in the cooling system, normal machine operation and no reaction of the machine operator to the fault signal status. Two of the abovementioned events have their causes, which, connected by a logic gate "or" in the fault tree, indicate their independence. In this case there are many alternative scenarios for the course of the event - from the initial to the top event. Figure 3 shows the use of the fault tree for analysis of miner's accident hit during locomotive transport (carriage). 


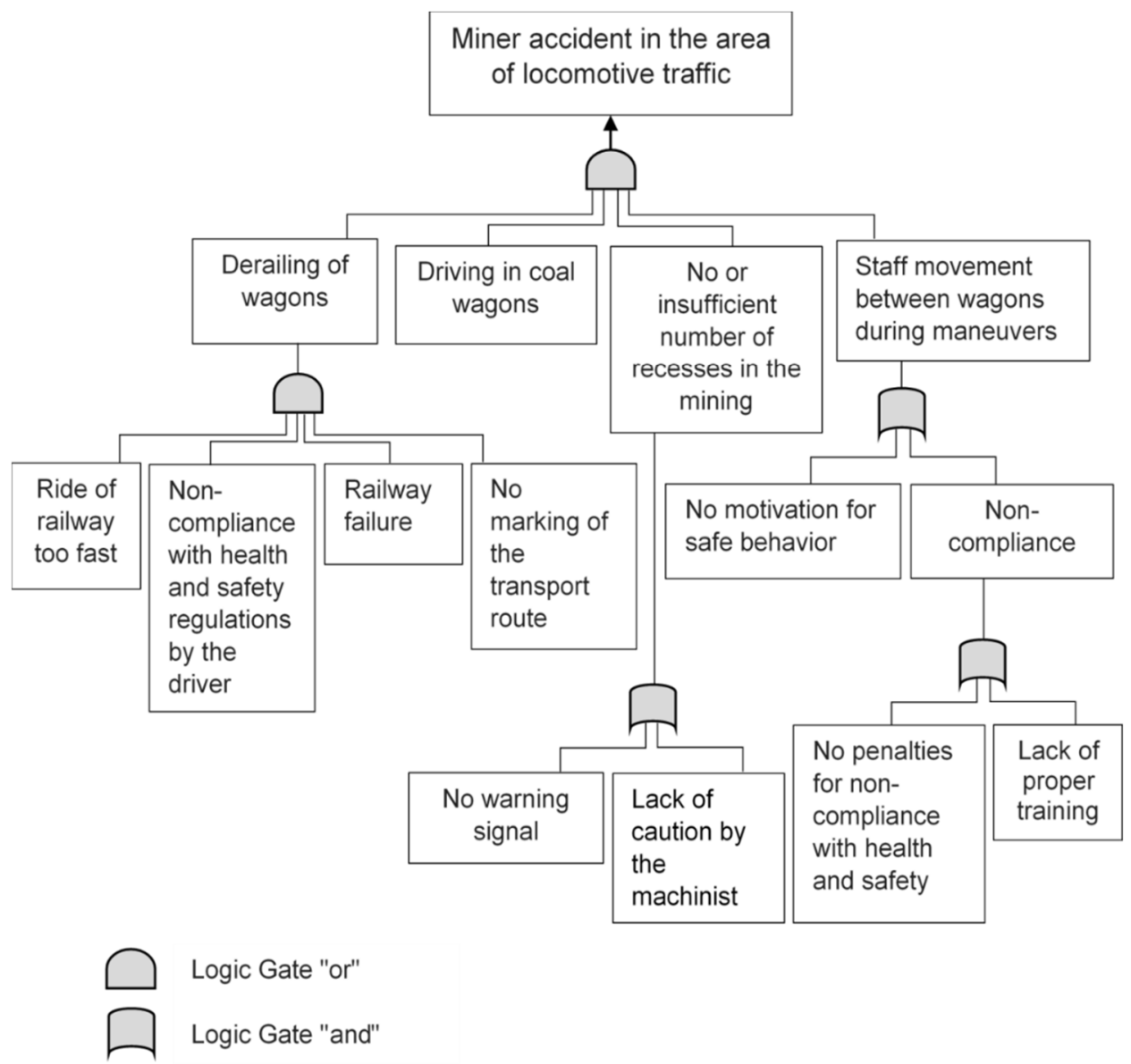

Fig. 3. Diagram of fault tree for accident event in the locomotive transport area in mining - own study

The immediate causes of this accident may be: employees riding on coal wagons, staff movement between wagons during maneuver of railway wagons, lack of appropriate number of recesses in transport sidewalks and derailment of wagons. These direct threats have many indirect causes such as: too fast driving railway wagons, non-compliance of occupational safety regulations by employees (including engine drivers), lack of proper marking of transport routes and warning signals, technical defects and lack of motivation for safe behaviour among employees.

\section{DISCUSSION}

The main objective of occupational risk assessment is to ensure the improvement of safety and health protection of employees. The effectiveness of the occupational health and safety management system functioning in the organization depends to a large extent on the method of conducting this assessment. Every employer is obliged to inform employees about the risks they are exposed to. For this purpose, it is necessary to estimate the amount of risk occurring in the plant, and then use the results obtained in:

- designing risk reduction activities,

- informing employees about the risks they are exposed to,

- creating a system blocking access to difficult and especially dangerous tasks for people without proper preparation.

A very important element of the risk assessment procedure is the identification of the list of threats. The estimated risk size depends on the reliability of the list of threats. In the presented examples: accident and machine breakdown, most of the causes are related to the behaviour of people in the workplace. The development of the event scenario depends on the behaviour 
of the employees. The human errors that are repeated in the presented events are: lack of caution, lack of motivation for safe behaviour, non-compliance.

\section{CONCLUSIONS}

The human factor has a large share in the identified causes of accidents and breakdowns in the work environment. Human errors in all applied safeguards and risk analysis should be taken into account. Methods of risk reduction should also be used to reduce risks and target people. The first group can include activities such as:

- reduction of hazardous energy parameters (voltage, pressure, weight, speed, etc.),

- elimination of hazardous materials and substances or substitution of others with higher safety parameters,

- reducing the time of exposure to hazards,

- moving the employee away from energy sources or dangerous material,

- limiting the employee's contact with dangerous material (for examle protective barriers, protective clothing),

- specifying a detailed procedure for the safe execution of the task.

Actions aimed at people include:

- employee training in the field of occupational health and safety,

- providing information about threats,

- providing appropriate and specialized tools,

- adjusting tasks to physical and mental predispositions of employees,

- motivating people to take safe work methods (Gembalska-Kwiecień, 2016).

The activities listed above should be properly selected for tasks performed by employees in the company.

\section{ACKNOWLEDGEMENTS}

This article was prepared within the statutory research titled "Development of intelligent production methods as well as work and life environments in the context of production engineering challenges", work symbol 13/030/BK_18/0039 performed at Silesia University of Technology, Institute of Production Engineering.

\section{REFERENCES}

Bobrowski, D. (1980). Probabilistyka w zastosowaniach technicznych. Warszawa: Wyd. WNT.

Gembalska-Kwiecień, A. (2016). Proces przygotowania pracowników do podjęcia bezpiecznej pracy na przykładzie kopalni. In: H. Badura, A. Michna, S. Czerwiński ed., Systemy wspomagania w inżynierii produkcji. Górnictwo - perspektywy i zagrożenia, z. 1(13).

Hąbek, P. and Molenda, M. (2017). Using the FMEA method as a support for improving the social responsibility of a company. In: 6th International Conference on Operations Research and Enterprise Systems. ICORES 2017, Porto, Portugal, 23-25 February, 2017. Final program and book of abstracts. [B.m.] : SciTePress - Science and Technology Publications, p. 39.

Idzikowski, A. and Bajdur, W.M. (2011). Analiza i ocena ryzyka zawodowego na stanowisku ślusarza metodą wstępnej analizy zagrożeń - PHA. In: J. Tabor, Sz. Salamon, ed., Zarządzanie bezpieczeństwem i higieną pracy, T.2, Przegląd metod oceny ryzyka zawodowego, Wyd. WZ $\mathrm{PCz}$, Częstochowa.

Ignac-Nowicka, J. (2015). Application of elements of the teory of events to identify hazards in mining workplaces. Scientific Journals of the Maritime University of Szczecin, No. 42 (114), pp. 133-139.

Ignac-Nowicka, J. (2017). Analiza zagrożeń na wybranych stanowiskach pracy z zastosowaniem drzewa błędów. In: A. Kuboszek, E. Milewska, ed., Systemy wspomagania w inżynierii produkcji. Jakość, Bezpieczeństwo, Środowisko, vol. 6, is. 7.

Ignac-Nowicka, J. (2018). Application of the FTA and ETA method for gas hazard identification for the performance of safety systems in the industrial department. Management Systems in Production Engineering. vol. 26, No. 1, pp. 23-26.

Kalinowski, R. (2003). Monitorowanie zagrożeń. Siedlce: Wyd. Akademii Podlaskiej.

Kotus, M., Burda, M., Pauliček, T. and Kiedrowicz M. (2014). Risk assessment of decreasing the failure of thermal liquid collector. Menagement Systems in Production Engineering, vol. 1(13), pp. 1012. 
Pauliček, T., Čičo, P., Zaujec, J. and Burda, M. (2012). Risk assessment and actions to reduction of risk in explosive environment. Menagement Systems in Production Engineering, vol. 3(7), pp. 18-20.

PN-N-18001 (2004). Systemy zarządzania bezpieczeństwem i higieną pracy. Wymagania. Warszawa: Wyd. PKN.

Studenski, R. (1996). Organizacja bezpiecznej pracy w przedsiębiorstwie. Gliwice: Wyd. Politechniki Śląskiej, pp. 64-65. 